\title{
Hak-Hak Perempuan Enggano Dalam Sistem Kekerabatan Matrilineal
}

\author{
Susi Ramadhani ${ }^{1}$ \\ Noeke Sri Wardhani ${ }^{2}$ \\ Lentiara Putri ${ }^{3}$ \\ Fakultas Hukum Universitas Bengkulu \\ ${ }^{1}$ Email : sramadhani@unib.ac.id \\ ${ }^{2}$ Email: nswardhani@unib.ac.id \\ ${ }^{3}$ Email : lentiara@unib.ac.id
}

\begin{abstract}
This study aims to explore knowledge about the matrilineal system embraced by the Enggano tribe and inventory what rights are owned by the Enggano women in the matrilineal system and describe the implementation of these rights in the life of the Enggano tribe on Enggano Island. This research is an empirical legal research. Data obtained from the community, so that it will get data that directly occurs in the community. The results showed that the notion of matrilineal in the kinship system was already understood by the majority of adat leaders in Enggano. A matrilineal system that inherits maternal lineages to their daughters and sons. It is the daughter who can later pass the tribal lineage to her children, but there are exceptions if the boy is an only child so the mother's tribe can be passed on to him. Disputes over the rights of Enggano women have never occurred in the indigenous Enggano community. Dispute resolution if it occurs then it is settled in a family first if no agreement is reached then proceed to customary deliberations by involving tribal leaders such as the Chief of the Tribe, the Chief of the Customs, the Customary Treasurer, community leaders, village officials and the disputing parties.
\end{abstract}

Keywords: Enggano Island; Matrilineal; Women

\begin{abstract}
ABSTRAK
Penelitian ini bertujuan menggali pengetahuan tentang sistem matrilineal yang dianut oleh suku Enggano dan menginventarisasi hak-hak apa saja yang dimiliki oleh perempuan suku Enggano dalam sistem matrilineal serta mendiskripsikan implementasi hak-hak tersebut dalam kehidupan masyarakat suku Enggano di Pulau Enggano. Penelitian ini adalah penelitian hukum empiris. Data diperoleh dari masyarakat, sehingga akan mendapatkan data yang langsung terjadi dalam masyarakat. Hasil penelitian menunjukkan bahwa pengertian matrilineal dalam sistem kekerabatan sudah dimengerti oleh sebagian besar Ketua adat di Enggano. Sistem matrilineal yang menurunkan garis keturunan dari pihak Ibu kepada anak perempuan dan anak laki-lakinya. Anak perempuanlah yang nanti dapat menurunkan garis keturunan suku kepada anak-anaknya, tetapi terdapat pengecualian apabila anak laki-laki adalah anak tunggal maka suku Ibunya dapat diturunkan kepadanya. Sengketa terhadap hak-hak perempuan Enggano belum pernah terjadi di masyarakat adat Enggano. Penyelesaian sengketa apabila terjadi maka diselesaikan secara kekeluargaan terlebih dahulu apabila tidak dicapai kesepakatan maka dilanjutkan ke musywarah adat dengan melibatkan pengurus suku seperti Kepala Pintu Suku, Ketua Adat, Bendahara Adat, tokoh masyarakat, perangkat Desa dan pihak yang bersengketa.
\end{abstract}

Kata Kunci: Enggano; Matrilineal; Perempuan 


\section{Pendahuluan}

Bangsa Indonesia merupakan bangsa yang masyarakatnya memiliki keragaman suku, ras, agama dan adat kebiasaan yang tersebar di kota-kota dan desa-desa. Keragaman itupun menjadi suatu kekayaan akan potensi yang dimiliki oleh bangsa Indonesia. Dalam kehidupan bermasyarakat, masyarakat dan hukum merupakan dua hal yang tidak dapat dipisahkan (ubi societas Ibi $i u s)^{1}$, dimana ada masyarakat dan di situ ada hukum. Oleh karena itu dibutuhkan suatu aturan hukum untuk mengatur kehidupan bermasyarakat demi mencapai ketertiban umum. Aturan hukum tersebut ada yang tertulis dan tidak tertulis, yang berlaku secara nasional maupun kedaerahan, di dalam lapangan hukum publik maupun hukum privat.

Pengakuan kembali terhadap berlakunya hukum adat mulai sejak dikeluarkannya Undang-undang No.1 Darurat Tahun 1951(UU No.1 Drt/1951), pengakuan kembali bahwa "hukum yang hidup" (hukum adat yang tidak tertulis) dapat menjadi sumber hukum pidana tertulis, selama tidak ada padanannya dalam

\footnotetext{
1 "Ubi societas ibi ius" atau yang diterjemahkan dalam bahasa Indonesia "Dimana ada masyarakat disitu ada hukum" adalah perkataan dari Marcus Tullius Cicero seorang filsuf,ahli hukum, dan ahli politik kelahiran Roma. "Ubi societas ibi ius", https://ramadhanadi.wordpress.com/2013/11/29/ubisocietas-ibi-ius-ada-masyarakat-ada-hukum/, 20 Maret 2018.
}

WvS (Wetboek van Strafrecht)/KUHP. ${ }^{2}$ Dasar Berlakunya hukum adat juga terdapat dalam Pasal 18B ayat (2) Undang-Undang Dasar 1945 yang menerangkan bahwa negara mengakui dan menghormati kesatuan-kesatuan masyarakat hukum adat beserta hak-hak tradisionalnya sepanjang masih hidup dan sesuai dengan perkembangan masyarakat dan prinsip Negara Kesatuan Republik Indonesia, yang diatur dalam undang-undang ${ }^{3}$.

Keberlangsungan hukum adat tidak terlepas dari keturunan dari masyarakat adat tersebut. Keturunan merupakan unsur yang essensiil serta mutlak bagi sesuatu clan, suku ataupun kerabat yang menginginkaan dirinya tidak punah, yang menghendaki supaya ada generasi penerusnya ${ }^{4}$. Keturunan dapat dilihaat dari keturunan garis Bapak (patrilineal) dan keturunan garis Ibu (matrilineal) $)^{5}$. Mayoritas suku di Indonesia menganut sistem kekerabatan patrilineal namun ada beberapa suku yang menganut sistema matrilineal.

Suku yang menganut sistem matrilinel di Indonesia salah satunya adalah suku

${ }^{2}$ Mardjono Reksodiputro, Pembaharuan Hukum Pidana, Kumpulan Karangan Buku Keempat (Jakarta: Pusat Pelayanan Keadilan dan Pengabdian Hukum, 2007) hlm. 99.

${ }^{3}$ Indonesia, Undang-Undang Dasar 1945, ps. 18B ayat (2).

${ }^{4}$ Surojo Wignjodipuro, Pengantar dan Azaz-azas Hukum Adat, Edisi III,(Bandung: Penerbit Alumni, 1979) hlm. 128.

${ }^{5}$ Ibid. hlm. 130 
Minangkabau ${ }^{6}$ Selain dari dari suku Minangkabau, suku Enggano yang terletak di Pulau Enggano Kecamatan Enggano Kabupaten Bengkulu Utara juga menganut sistema kekerabatan matrilineal ${ }^{7}$. Hal ini dilihat dari nama marga suku diwariskan dari garis keturunan Ibu. Suku Enggano masih mempertahankan keberadaan adat istiadat dalam kehidupan sehari-hari masyarakatnya. Hukum adat masih menjadi pedoman dalam kehidupan masyarakat Enggano dan ditaati. Fungsionaris adat yang terdiri dari Paabuki, Kepala Suku dan Kepala Pintu Suku.

Pulau Enggano merupakan salah satu pulau terluar berpenduduk yang terletak di Kabupaten Bengkulu Utara Propinsi Bengkulu ${ }^{8}$. Pada Tahun 2016 jumlah penduduk Kecamatan Enggano mencapai 3.152 jiwa, terdiri dari 1.712 laki-laki dan 1.440 perempuan ${ }^{9}$ Matapencaharian masyarakat Enggano antara lain: bertani, berkebun, nelayan, berdagang, bekerja di bidang transportaasi dan sebagian kecil berprofesi sebagai Pegaawai Negeri Sipil.

${ }^{6}$ Ibid.

${ }^{7}$ Suku Enggano, Kementerian Sekretarian Negara Republik Indonesia, http://indonesia.go.id/?p=8564, 20 Maret 2018.

${ }^{8}$ Pulau Enggano, Kementerian Kelautan dan Perikanan, http://www.ppk-kp3k.kkp.go.id/direktoripulau/index.php/public c/pulau_info/295, 20 Maret 2018.

${ }^{9}$ Badan Pusat Statistik Kabupaten Bengkulu Utara,Kecamatan Enggano Dalam Angka 2017,
Kecamatan Enggano merupakan kecamatan terjauh dari ibukota Kabupaten Bengkulu Utara. Transportasi untuk menuju Pulau Enggano melalui jalur laut, yaitu dengan menggunakan kapal ferry atau perintis melalui pelabuhan Pulau Baai Kota Bengkulu dengan waktu tempuh sekitar 12 jam lebih, sedangkan melalui jalur udara dengan pesawat perintis waktu tempuh sekitar 40-50 menit dari Bandara Fatmawati Bengkulu.

Keterkaitan penelitian dengan Renstra Penelitian Unib 2012-2020 yang menetapkan target 2020 yakni "Model pemanfaatan kawasan hutan tropis dan pesisir yang spesifik dan berkesinambungan untuk mendorong terwujudnya sentra produksi dan pengolahan hasil bumi bagi kesejahteraan masyarakat". Pencapaian visi 2020 tersebut diupayakan secara bertahap ke dalam beberapa topik penelitian, dan pada tahun 2016-2018 topik yang sudah ditentukan yaitu "Pengembangan model konstruksi sosial mengenai masalah sosial, kesehatan, pendidikan, ekonomi, hukum, kebijakan, lingkungan kawasan hutan tropis dan pesisir, serta kebencanaan dan perilaku kewaspadaan bencana pada masyarakat kawasan hutan tropis dan pesisir" Secara konkrit penelitian ini akan menghasilkan inventarisasi hak-hak perempuan Enggano dalam hukum adatnya yang menganut sstem matrilineal, sehingga 
akan didapatkan gambaran tentang eksistensi hukum adat Enggano. Dengan demikian penelitian yang diajukan ini memiliki cantelan pada Rencana Induk Penelitian Unib.

Keberadaan masyarakat suku Enggano yang terletak di pulau terluar Indonesia dengan akses transportasi yang terbatas membuat Pulau Enggano sedikit terisolir sehingga keadaan sosial budaya masyarakat Enggano jarang diketahui oleh masyarakat luar Enggano. Keberadaan hukum adat yang masih berlaku dan ditaati serta sistem kekerabatan matrilineal yang dianut masyarakat suku Enggano menjadikan penelitian ini penting untuk dilakukan.

Masalah yang akan dikaji dalam penelitian ini yaitu bagaimanakah sistem kekerabatan matrilineal yang dianut oleh suku Enggano termasuk didalamnya membahas, bagimanakah hak-hak perempuan suku Enggano dalam sistem matrilineal dan bagaimanakah penyelesaian sengketa terhadap hak-hak perempuan suku Enggaano yang menganut sistem kekerabatan matrilineal

Tulisan ini bertujuan untuk menggali pengetahuan tentang sistem matrilineal yang dianut oleh suku Enggano dan menginventarisasi hak-hak apa saja yang dimiliki oleh perempuan suku Enggano dalam sistem matrilineal serta mendiskripsikan implementasi hak-hak tersebut dalam kehidupan masyarakat suku Enggano di Pulau Enggano. Hal lain yang ingin dituju dalam penelitian ini adalah menemukenali penyelesaian sengketa yang terjadi terhadap hak-hak perempuan suku Enggano dalam sisten kekerabatan matrilineal.

\section{Analisis dan Pembahasan}

\section{A. Sistem Kekerabatan Matrilineal Suku Enggano}

Sistem kekerabatan matrilineal yang menurunkan garis keturunan menurut garis keturunan Ibu sangat menarik untuk diketahui karena mayoritas suku yang ada di Indonesia menganut sistem kekerabatan patrilineal dimana garis keturunan diturunkan dari pihak Ayah. Sistem matrilineal yang dianut oleh masyarakat suku Enggano, dideskripsikan dalam hasil penelitian berikut ini: Sistem matrilineal menurut Bapak Musa Kahoau (Kepala Pintu Suku Kahoa): Matrilineal yang diketahui oleh bapak Musa Kahoau adalah suku adat Enggano menurun kepada anak lakilaki atau anak perempuan dan suku yang diturunkan berdasarkaan suku Ibu. Anak perempuanlah yang dapat menurunkan suku Ibu. Garis keturunan suku Enggano diturunkan kepada anak hasil pernikahan (anak kandung). Suku yang diterima oleh seorang anak tidak bisa dibatalkan, kalaupun ada yang 
membatalkan nama suku seseorang, kaumnya (warga sukunya) tetap memanggil nama suku orang tersebut.

Sistem matrilineal menurut Bapak Johansen Kaarubi (Ketua Suku Kaarubi): Garis keturunan diturunkan kepada anak perempuan. Anak laki-laki dapat meneruskan garis keturunan suku apabila anak laki-laki tersebut merupakan anak tunggal dalam keluarganya, hal ini dikarenakan anak laki-laki inilah yang akan menggantikan suku Ibunya. Garis keturunan (nama suku) dapat dibatalkan apabila penerima garis keturunan menyalahi aturan suku.

Sistem matrilineal menurut Bapak Mulyadi Kauno (Kepala Pintu Suku kauno): Pengertian sistem matrilineal menurut bapak Mulyadi Kauno adalah garis keturunan dari pihak perempuan, dari suku Ibu dan diturunkan kepada anak laki-laki dan perempuaannya. Nama suku yang diturunkan seorang Ibu suku Enggano kepada anakanaknya tidak dapat dibatalkaan.

Sistem matrilineal menurut Bapak M. Rafli Zen Kaitora (Kepala Suku Kaitora) : Bapak Rafli Zen mengemukakan bahwa pengertian matrilineal adalah alur keturunan dari pihaak Ibu. Garis keturunan ini diturunkaan kepada anak perempuan dan nama suku yang didapat karena garis keturunan tidak ada yang dapatt membatalkan.
Sistem matrilineal menurut Bapak M.Jorri Kaahua (Kepala suku Kaahoa): Setiap anak mengikuti suku Ibu merupakan pengertiaan matrilineal menurut Bapak M.Jorri Kaahua. Garis keturunan diturunkan kepada anak perempuan hasil pernikahan antar suku Enggano satu dengan suku Enggano yang lain dan berkembangnya suku meneruskan garis suku Ibu. Tidak ada yang bisa membatalkaan nama suku seseorang kecuali orang tersebut mengucapkaan perkataan ingin keluar daari susku maaka diaa wajib dikeluarkan.

Sistem matrilineal menurut Bapak A.F.Abner Kaarubi (Ketua Suku Pintu Kaarubi Ahepea) : Matrilineal adalah garis keturunan mengikuti alur daari suku Ibu dan tidak bisa dibatalkan. Pembatalan nama suku walaupun orang itu sendiri yang melakukannya kaumnya (sukunya) tetaap memaanggil orang tersebut dengan nama sukunya.

Pengertian matrilineal dalam sistem kekerabatan sudah dimengerti oleh sebagian besar Ketua adat di Enggano. Sistem matrilineal yang menurunkan garis keturunan dari pihak Ibu kepada anak perempuan dan anak laki-lakinya. Anak perempuanlah yang nanti dapat menurunkan garis keturunan suku kepada anak-anaknya, tetapi terdapat pengecualian apabila anak laki-laki adalah anak tunggal maka suku Ibunya dapat 
diturunkan kepaadanya ${ }^{10}$. Anak tunggal lakilaki inilah yang nanti akan menggantikan Ibunya (meneruskan suku Ibunya kepada anak-anaknya).

Garis keturunan Ibu diturunkan seorang Ibu kepada anaknya yang merupakan hasil pernikahnnya dengan laki-laki dari Suku Enggano yang lain maupun laki-laki dari luar Enggano. Anak hasil pernikahan inilah yang akan mendapatkan garis keturunan suku Ibunya. Suku Enggano hanya diturunkan kepada anak kandung ${ }^{11}$ dan nama suku yang diturunkan tidak dapat dibatalkan kecuali orang tersebut melakukan pelanggaran ketentuan dalam sukunya dan keluar dari sukunya.

\section{B. Hak-Hak Perempuan Suku Enggano dalam Sistem Matrilineal}

Hak-Hak Perempuan Suku Enggano dalam Sistem Matrilineal menurut Bapak Musa Kahoau (Kepala Pintu Suku Kahoa). Hak hak yang dimiliki oleh perempuan suku Enggano dalam sistem matrilineal berupa rumah, ternak dan tanah yang

\footnotetext{
${ }^{10}$ Wawancara dengan Bapak Johansen Kaarubi, Ketua Suku Kaarubi, tanggal 6 Oktober 2018.

11 Wawancara dengan Bapak M.Jorri Kaahua, Ketua Suku Kaahoa, Bapak Johansen Kaarubi, Bapak Musa Kahoua, Ketua Pintu Suku Kahoau, Bapak Mulyadi Kauno, Kepala pintu Suku Kauno, Bapak aflizen Kaitora, KepalaSuku Kaitora, dan Bapak A.F. Abner Kaarubi, Ketua Suku Pintu Kaarubi Ahepea.
}

dibuat/dikerjakan oleh orang tuanya. Seorang perempuan suku Enggano dalam kepengurusan adatnya memiliki jabatan sebagai Bendahara Suku yang disebut "Orai". Syarat-syarat yang harus dimiliki oleh perempuan Enggano yang menjadi bendahara suku adalah perkawinannya dilangsungkan secara adat (kawin adat). Seorang bendahara adat mewarisi beberapa peninggalan sukunya seperti parang adat dan tombak.

Hak-Hak Perempuan Suku Enggano dalam Sistem Matrilineal menurut Bapak Johansen Kaarubi (Ketua Suku Kaarubi) : Seorang anak perempuan suku Enggano dapat mewarisi tanah, rumah, kebun dan ternak dari orang tuanya. Perempuan Enggano dapat memiliki jabatan sebagai bendahara suku adat atau disebut dalam bahasa Enggano sebagai "Orai". Syarat yang harus dimiliki untuk menjadi seorang bendahara adat antara lain telah berkeluarga, harus mengerti adat dan paham bahasa Enggano. Seorang bendahara adat harus selalu aktif dalam setiap urusan adat dan dalam kepengurusan adat.

Hak-Hak Perempuan Suku Enggano dalam Sistem Matrilineal menurut Bapak Mulyadi Kauno (Kepala Pintu Suku kauno) : Warisan yang diberikan kepada anak perempuan berupa rumah dan kebun. Perempuan suku Enggano berhak mempunyai jabatan sebagai bendahara adat disebut "Orai". 
Hak-hak yang dimiliki perempuan suku tersebut bisa mengemban jabatan di dalam Enggano menurut adat Enggano yaitu adatnya.

perempuan suku Enggano bisa mendirikan

Hak-Hak Perempuan Suku Enggano rumah "Hatus Kaudar" (wilayah tanah adat). dalam Sistem Matrilineal menurut Bapak A.F.

Hak-Hak Perempuan Suku Enggano dalam Sistem Matrilineal menurut Bapak M. Rafli Zen Kaitora (Kepala Suku Kaitora) : Perempuan suku Enggano memiliki jabatan dalam kepengurusan adat suku Enggano sebagai bendahara suku. Hak perempuan yang dimiliki oleh perempuan suku Enggano berupa rumah, tanah dan ternak.

Hak-Hak Perempuan Suku Enggano dalam Sistem Matrilineal menurut Bapak M.Jorri Kaahua (Kepala suku Kaahoa). Hakhak yang dimiliki seorang perempuan suku Enggano adalah rumah merupakan hak utama bagi anak perempuan, kebun juga akan diberikan tergantung kesepakatan keluarga. Warisan yang diberikan oleh orang tua kepada anak perempuan suku Enggano berupa rumah, kebun, peralatan rumah, ternak dan sepertiga dari harta yang ada untuk anak perempuan. Jabatan yang dimiliki oleh perempuan suku Enggano dalam kepengurusan adat sebagai bendahara suku dan tata seni budaya. Syaratsyarat yang harus dimiliki oleh penerima garis keturunan adalah aktif dalam kegiatan adat dan musyawarah adat, cakap dalam berbicara, dan apabila syarat ini dipenuhi maka perempuan Abner Kaarubi (Ketua Suku Pintu Kaarubi Ahepea). Hak-hak sebagai perempuan suku Enggano menurut adat suku Enggano adalah boleh memilih tetapi tidak boleh dipilih sebagai ketua suku. Warisan yang diberikan kepada anak perempuan suku Enggano berupa rumah, peralatan rumah dan tanah, itupun tergantung kesepakatan keluarga. Jabatan dalam kepengurusan adat suku Enggano hanya sebagai bendahara suku. Syarat yang harus dipenuhi sebagai bendahara suku telah berkeluarga.

Suku Enggano yang menurunkan garis keturunan dari pihak Ibu dalam kehidupan bermasyarakatnya menjadikan perempuan suku Enggano sebagai Bendahara Suku/Adat. Jabataan inilah yang dapaat dimiliki oleh seorang perempuan dalam kepengurusan sukunya. Bendahara suku/adat hanya dapat dijabat oleh perempuan suku Enggano apabila telah menikah, pernikahnnya diilangsungkan dengan adat Enggano (Kawin Adat). Syarat lain yang harus dimiliki adalah cakap berbicara, mengerti bahasa Enggano, aktif dalam kepengurusan adat dan aktif dalam musyawarah adat. Seorang Bendahara Adat/Suku memiliki tugas untuk menyimpan 
harta peninggalan sukunya berupa parang, tombak, kalung kerang, topi adat dan peninggalan-peninggalan lainnya.

Warisan yang diberikan di sebagian besaar Suku merupakan kewajiban yang harus dipenuhi orang tua kepada anak perempuaannya tetapi ad ajuga yang berpendapat ini bukanlah suatu keharusan Perempuan suku Enggano mewarisi rumah, tanah, ternak dan peralatan rumah dari orang tuanya, tergantung kepada orang tua apa yang ingin diberikannya kepada anak perempuannya. Seorang perempuan suku Enggano memiliki hak untuk memilih ketua adat tetapi tidak dapat dipilih sebagai ketua adat.

\section{Penyelesaian Sengketa Terhadap Hak- Hak Perempuan Suku Enggaano yang Menganut Sistem Kekerabatan Matrilineal}

Penyelesaian Sengketa terhaadap HakHak Perempuan Suku Enggano menurut Bapak Musa Kahoau (Kepala Pintu Suku Kahoa). Tidak pernah terjadi sengketa apapun terhadap hak-hak perempuan Suku Enggano, jikapun ada diselesaikan dalam keluarga saja. Pihak yang terlibat dalam penyelesaian dalam penyelesaian sengketa terhadap hak hak perempuan suku Enggano adalah ketua suku, bendahara suku dan kepala desa. Penyelesaian sengketa dapat dilakukan di rumah adat, atau rumah yang bersangkutan. Tidak ada waktu yang diberikan untuk menyelesaikan sengketa tersebut.

Penyelesaian Sengketa terhaadap HakHak Perempuan Suku Enggano menurut Bapak Johansen Kaarubi (Ketua Suku Kaarubi). Tidak pernah ada sengketa terhadap hak-hak perempuan suku Enggano yang terjadi di masyarakat suku Enggano. Kalapun ada diselesaikan secara adat dengan melibatkan kedua belah pihak suku bapak dan suku ibu. Apabila tidak terjadi kesepakatan maka dilakukan musyawarah kembali yang dihadiri oleh kepala suku dan bendahara adat. Tempat penyelesaian sengketa dilaukan di rumah adat atau di rumah pihak suku bapak. Tidak ada batas waktu yang ditentukan dalam menyelesaikan sengketa terhadap hak-hak perempuan suku Enggano. Tidak ada sanksi yang diberikan dalam hal terjadi sengketa terhadap hak-hak perempuan suku Enggano.

Penyelesaian Sengketa terhaadap HakHak Perempuan Suku Enggano menurut Bapak Mulyadi Kauno (Kepala Pintu Suku kauno), Penyelesaian sengketa terhadap hakhak perempuan suku Enggano dilakukan dalam musyawarah adat. Pihak-pihak yang terlibat dalam penyelesaian sengketa terhadap hak-hak perempuan suku Enggano seperti 
kepala suku, bendahara adat/Kahue Ora dan Pabuki. Tempat dilaksanakannya penyelesaian sengketa dilakukan di Kaudar/ wilayah adat. Tidak ada tenggang waktu dalam sengketa terhadap hak-hak perempuan suku Enggano. Sanksi yang diberikan dalam hal terjadinya sengketa terhadap hak-hak perempuan suku Enggano berupa kirdiyoh/didenda. Bagi yang melakukan kesalahan apabila akan melangsungkan pernikahan adat harus menyelesaikan sengketa dengan cara memohon maaf kepada kepala suku dari pihak yang disengketakan dan meminta maaf kepada dua Kepala Pintu Suku. Sanksi lain yang dapat dijatuhkan adalah pemberian parang dan uang denda.

Penyelesaian Sengketa terhaadap HakHak Perempuan Suku Enggano menurut Bapak M. Rafli Zen Kaitora (Kepala Suku Kaitora), Penyelesaian Sengketa terhaadap Hak-Hak Perempuan Suku Enggano apabila terjadi diselesaikan secara adat Enggano. Pihak yang terlibaat daalam penyelesaian sengketa antara lain Kepaalal Suku , Kepala Pintu Suku dan Bendahara Adat/Orai. Penyelesaian dilakukan di rumah adat atau rumah pihak yang bersengketa dan tidak ada tenggat waktu yang ditentukan dalam penyelesaian sengketa. Beberapa sanksi yang dapat dijatuhkan apabila terjadi sengketa adalah membuat suatu acara dan mengundang seluruh pemuka adat dan tokoh masyarakat.

Penyelesaian Sengketa terhaadap HakHak Perempuan Suku Enggano menurut Bapak M.Jorri Kaahua (Kepala suku Kaahoa). Sengketa yang terjadi terhadap hak-hak perempuan suku Enggano akan dibawa ke musyawarah di dalam lembaaga adat Enggano apabila tidak ditemukan kesepakatan dalam keluaarga, maka diminta penyelesaian dalam tata cara adat Enggano. Para pihak yang dilibatkan dalam penyelesaian sengketa terhadap hak-hak perempuan suku Enggano antara lain: Kepala Suku, Kepala Pintu Suku, Pabuki serta seluruh pemuka adat yang ada dalam kelembagaan. Pelaksanaannya dilaksanakan di rumah adat, dirumah Kepala Suku atau di kantor pemerintahan yang ada. Adapaun sanksi yang dapat dijatuhkan adalah denda adat berupa uang sesuai hasil muasyawarah kedua belah pihak yang bersengketa.

Penyelesaian Sengketa terhaadap HakHak Perempuan Suku Enggano menurut Bapak A.F. Abner Kaarubi (Ketua Suku Pintu Kaarubi Ahepea), Menurut adat Enggano, tidak pernah terjadi sengketa, kalaupun ada diselesaikan oleh Ketua Suku dan Bendahara Adat (Ora/Khue). Pihak yang terlibat dalam penyelesaian sengketa adalah tokoh adat, Kepala Suku dan Bendahara Suku. 
Penyelesaian sengketa dilaksanakan di rumah adat suku atau rumah Bendahara Adat (Ora/Khue). Waktu yang diperlukan dalam penyelesaian sengketa tidak bias ditentukan berapa lama. Adapun sanksi yang bias dijauhkan apabila terjadi sengketa adalah dikembalikannya benda atau warisan yang disengketakan kepada pihak yang berhak menerima.

Sengketa terhadap hak-hak perempuan Enggano belum pernah terjadi di masyarakat adat Enggano. Penyelesaian sengketa apabila terjadi maka diselesaikan secara kekeluargaan terlebih dahulu apabila tidak dicapai kesepakatan maka dilanjutkan ke musywarah adat dengan melibatkan pengurus suku seperti Kepala Pintu Suku, Ketua Adat, Bendahara Adat, tokoh masyarakat, perangkat Desa dan pihak yang bersengketa.

Penyelesaian sengketa biasanya dilakukan di rumah adat suku pihak yang bersengketa atau dirumah pihak yang bersengketa. Adapun sanksi yang dapat dijatuhkan adalah membuat suatu acara dan mengundang seluruh pemuka adat dan tokoh masyarakat, denda adat berupa uang sesuai hasil musyawarah kedua belah pihak yang bersengketa, dikembalikannya benda atau warisan yang disengketakan kepada pihak yang berhak menerima dan memohon maaf kepada kepala suku dari pihak yang disengketakan dan meminta maaf kepada dua Kepala Pintu Suku. Sanksi lain yang dapat dijatuhkan adalah pemberian parang dan uang denda

\section{Penutup}

Pengertian matrilineal dalam sistem kekerabatan sudah dimengerti oleh sebagian besar Ketua adat di Enggano. Sistem matrilineal yang menurunkan garis keturunan dari pihak Ibu kepada anak perempuan dan anak laki-lakinya. Anak perempuanlah yang nanti dapat menurunkan garis keturunan suku kepada anak-anaknya, tetapi terdapat pengecualian apabila anak laki-laki adalah anak tunggal maka suku Ibunya dapat diturunkan kepaadanya.

Perempuan suku Enggano berhak mewarisi rumah, tanah, ternak dan peralatan rumah dari orang tuanya, tergantung kepada orang tua apa yang ingin diberikannya kepada anak perempuannya. Seorang perempuan suku Enggano memiliki hak untuk memilih ketua adat tetapi tidak dapat dipilih sebagai ketua adat. Jabatan yang dapat dimiliki oleh perempuan suku Enggano dalam kepengurusan sukunya dalaah menjadi Bendahara Adat.

Sengketa terhadap hak-hak perempuan Enggano belum pernah terjadi di masyarakat adat Enggano. Penyelesaian sengketa apabila terjadi maka diselesaikan secara kekeluargaan 
terlebih dahulu apabila tidak dicapai kesepakatan maka dilanjutkan ke musywarah adat dengan melibatkan pengurus suku seperti Kepala Pintu Suku, Ketua Adat, Bendahara Adat, tokoh masyarakat, perangkat Desa dan pihak yang bersengketa.

Saran yang dapat diberikan yakni perlu dilakukan dokumentasi terkait adat suku Enggano, karena Ketua adat dan tokoh masyarakat yang ada sekarang telah berusia lanjut sehingga ditakutkan keberadaan adat Enggano di masa yang akan datang akan pudar dan tidak diketahui oleh generasi muda suku Enggano.

\section{Daftar Pustaka}

Badan Pusat Statistik Kabupaten Bengkulu Utara,Kecamatan Enggano Dalam Angka 2017, Bengkulu Utara: BPS Kab. Bengkulu Utara, 2017.

Hadikusuma, Hilman Pengantar Ilmu Hukum Adat Indonesia, Bandung: Mandar Maju, 2003.

Indonesia, Undang-Undang Dasar 1945

Munir, Minal, "Sistem Kekerabatan dalam Kebudayaan Minangkabau: Perspektif Aliran Filsafat Stukturalisme Jean Claude LeviStrauss" Jurnal Filsafat Vol. 25, No. 1 (Februari 2015), $<$ https://media.neliti.com/media/publi cations/80992-ID-sistemkekerabatan-dalam-kebudayaanmina.pdf>, 20 Maret 2018
Moleong, Lexy.J, Metodologi Penelitian Kualitatif. Bandung: Rosdakarya, 1995.

"Peran Fungsionaris Lembaga Adat Dalam Penyelesaian Sengketa", https://www.suduthukum.com/2018/0 2/peran-fungsionaris-lembaga-adatdalam.html, 28 Februari 2018.

Pulau Enggano, Kementerian Kelautan dan Perikanan, $\quad$ http://www.ppkkp3k.kkp.go.id/direktoripulau/index.php/public_c/pulau_info/ 295, 20 Maret 2018.

Reksodiputro, Mardjono Pembaharuan Hukum Pidana, Kumpulan Karangan Buku Keempat Jakarta: Pusat Pelayanan Keadilan dan Pengabdian Hukum, 2007.

Saptomo, Ade Pokok-pokok Metodologi Penelitian Hukum Empiris Murni Sebuah Alternatif. Jakarta:Universitas Trisakti, 2009

Takdir Rahmadi, Mediasi Penyelesaian Sengketa Melalui Pendekatan Mufakat, Jakarta: Rajawali Pers, 2011.

Usman, Rachmadi,Mediasi di Pengadilan dalam Teori dan Praktek, Jakarta: Sinar Grafika, 2002.

Wignjodipuro, Surojo Pengantar dan Azazazas Hukum Adat, Edisi III, Bandung: Penerbit Alumni, 1979.

Suku Enggano, Kementerian Sekretarian Negara Republik Indonesia, http://indonesia.go.id/?p=8564, 20 Maret 2018. 